\title{
The Influence of Information Quality, System Quality and Service Quality on Student's Self-Efficacy at Institutions of Higher Learning in South Africa
}

\author{
Babatunde A.Popoola \\ Vaal University of Technology, Faculty of Management Sciences, Vanderbijlpark, 1900, South Africa \\ Email:popsonbabs4real@gmail.com \\ Richard Chinomona
}

Faculty of Commerce and Humanities, University of the Witwatersrand, Johannesburg, South Africa

Email: rchinos@hotmail.com

Elizabeth Chinomona

Vaal University of Technology, Faculty of Management Sciences, Vanderbijlpark, 1900, South Africa

Email: chakubvae@hotmail.com

Doi:10.5901/mjss.2014.v5n27p974

\section{Abstract}

The notion of improving student self-efficacy at institutions of higher learning has become a priority matter. There is a growing realization among institutions of higher learning that one way of achieving this, is by encouraging learners to make the best out of information technology use. It is therefore in this regards that this paper seeks to investigate the influence of information quality, system quality and service quality on student's self-efficacy at institutions of higher learning in South Africa. To address this dearth, this study proposed three hypotheses that were validated using a sample of 271 university students in the Gauteng province. The findings indicated that there are positive relationships between the posited research variables. Managerial implications of the findings are discussed and limitations and future research directions are indicated.

\section{Introduction}

In every organization, the importance of quality can never be over emphasized, be it in goods or service delivery. In higher educational system being a service delivery organization, there are different methods of ensuring that good and quality services are rendered to the society. The quality is more complex in higher education as opposed to in the industry where the output or outcomes are clearly defined. The quality in higher education as well as defining a way to measure is not a simple issue (Parri, 2006:107). According to Tang and Hussin (2011:126) are of concern about quality in higher education has always been in existence and is discernible in many ways. Due to the increasingly diverse student profile, it is imperative that stakeholders' views, especially the students', be taken into consideration by the higher education institutions for quality process improvement. This is supported by Srikanthan and Dalrymple (2003: 126) who advocated that the students' criteria for quality in higher education should be elucidated to provide them with an evidence of the comparatively high standards in order to guide their academic choices.

An essential measurement of any higher education institution is the education quality deliver in particularly teaching and learning environment. As the destiny of South Africa is currently being shaped in the lecture room, education has a number of important goals. In terms of the social constructivist paradigm, learning is a social process which is neither limited to an individual, nor is it passive, meaningful learning only takes place once an individual is engaged in social activities (Jackson, Karp, Patrick \& Thrower, 2006). These include developing the capability of students to use ideas and information, testing of ideas and evidence, generation of new ideas and evidence, facilitation of personal development and development of a student's capacity to plan and manage their learning culture and experience.

Moreover, quality assurance of higher education can never be overlooked. The term quality assurance can be classified to as a systematic, structured and continuous attention to quality in terms of quality maintenance and enhancement (Vroeijenstijn, 1995:30). Quality assurance is known to be used by all the departments at the higher institution to set the policies and priority. Brennan \& Shah (2000:157) espouse that the meaning of quality assurance as 
equivalent to academic standards is consistent with the emerging focus in higher education policies on student learning outcomes, the specific levels of knowledge, skills, and abilities that students achieve as a consequence of their engagement in a particular education program.

Quality being an important factor in every organization either being a manufacturing of goods or rendering of services to the society, therefore, this research paper will focus on the influence of information quality on student's selfefficacy, the influence of system quality on the student performance and lastly to determine service quality on student's self-efficacy at institutions of higher learning in South Africa.

\section{Problem Statement}

Though it is apparent that perceptions of service quality in higher education are based on multiple dimensions, there is no agreement as to the nature or content of these dimension (Brady \& Cronin, 2001: 34, Ko \& Pastore 2004:158). The student performance at the higher institution depends on the quality of information, system quality and service quality provided at the institution.

One of the challenges facing the higher institution is students' dissatisfaction which is related to customer satisfaction. Several empirical studies reported that service quality was an antecedent of customer satisfaction (Naik, Gantasala, \& Prabhakar, 2010:; Spreng and Mackoy, 1996:202). Hence, Naik, et al. (2010) stated that behavioural intention will effect by service quality but also mediated by customer satisfaction. In other words, when institution performed outstanding service quality, the customers will tend to make good behaviour in the future and also caused satisfactions. Another empirical problem is negative perception among students which is related to the university's image. It is another important factor in the overall evaluation of service and system quality (Aydin \& Ozer, 2005:910). University's image thus impacts a customer's evaluation of service quality, satisfaction and loyalty (Andreassen \& Lindestad, 1998:8; Zins, 2001:269).

Furthermore, another problem encounter by the higher institution in South Africa is the low pass rates and consequently throughput rates and this is as a result of poor information quality, service quality and system quality and this has being a problem to the Higher institution, student structures and also concern to the government. Given this background, this study work will be aimed at the influence of information quality, system quality and service quality on student's self-efficacy at institutions of higher learning in South Africa.

\section{Research Questions}

The following research questions were formulated:

- What is the influence of information quality on student self-efficacy at higher education?

- What is the influence of systems quality on student self-efficacy at higher education?

- How does the service quality have influence on the student performance at higher institution?

- What are the benefit of information, system and service quality at higher education?

\section{Aims of the Study}

The aim of this study is to determine the influence of information quality, system quality and service quality on the learner's or student's self-efficacy or learners outcomes or performance.

\section{Literature Review}

\subsection{Information Quality (Iq) In Higher Institution}

Information quality (IQ) has become a critical concern of organizations and this information can promote understanding of some of the key issues relevant to the design and implementation of a viable quality assurance system for South Africa higher education. IQ is pretty recognized as an essential and competitive strength in every organization and this will improve consumers' provider choices only if it considers the features of care that consumers perceive as relevant to their provider choices.

Information quality (IQ) is not an entirely new concept, but it has gained increasing attention during the last few years, both in business communities and higher institution. Much like information, the concept of quality is defined in 
different ways by different people. The problem of poor data and information quality is widespread and plays a critical role for every organization whose activity is based on communication and information. Insufficient quality of information and data often leads to numerous negative effects; which can disrupt business activities and interfere with decisions or can compromise communication and understanding among people.

According to DeLone and Mclean 1992:60, cited by Gorla, Somers \& Wong (2010:213), IQ refers to the quality of outputs the information system produces, which can be in the form of reports or online screens. Huh, Keller, Redman, \& Watkins (1990:559) define four dimensions of information quality: accuracy, completeness, consistency, and currency. Accuracy is agreement with an attribute about a real world entity, a value stored in another database, or the result of an arithmetic computation. Completeness is to be defined with respect to some specific application, and it refers to whether all of the data relevant to that application are present. While consistency refers to an absence of conflict between two datasets, currency refers to up-to-date information. Researchers have used a variety of attributes for information quality. Nelson, Todd, \& Wixom (2005: 200) have used the constructs of accuracy, completeness, currency, and format for information quality; the additional construct used by these authors format is related to the presentation layout of information outputs.

Moreover, it should be noted that data quality, fundamentally differs from that of information quality. Data quality refers to the quality of raw facts that reflect the characteristics of an event or entity, while information quality pertains to the quality of "meaningful data" where data have been converted into a meaningful and useful context (Detlor, Hupfer, \& Ruhi, 2010:120). Data quality is at the heart of information quality and poor data quality results in poor information quality. Poor data quality, and hence poor information quality, has adverse effects on organizations at operational, tactical, and strategic levels (Redman, 1998:79). In this respect, an example of data quality in the higher institution context would be the accuracy and correctness of the training or teaching given to the learners at a specific date, while an example of information quality in the higher institution context would be the accuracy and completeness of the assessment of the students.

Delone and McLean $(1992,2003: 10)$ mentioned that most measures of information quality are from the perspective of the user the information system and are subjective measures. It refers to measure of information and data for desired characteristics as the quality of output from a system included accuracy, precision, currency, reliability, completeness, conciseness, accessibility, adaptability, relevance, understandability, meaningfulness, timeliness, comparability and format. For information to be effective in higher institution, it must possess the aforementioned characteristics and must be easy-to-understand and consistent outputs.

\subsection{System Quality (Sq) In Higher Institution}

System quality can be referred to as the system that an organization uses to manage the quality of their services or products. And according to the International Organization for Standardization, defines a quality system as the management system used to direct and control an organization with regard to quality. SQ represents the quality of the information system processing itself, which includes software and data components, and it is a measure of the extent to which the system is technically sound. Seddon (1997:246) espouse that SQ is concerned with whether there are bugs in the system, the consistency of user interface, ease of use, quality of documentation, and sometimes, quality and maintainability of program code.

SQ is a series of actions designed to ensure consistency in approach, process and output. The outcome of a quality system is that the organisation has a sound basis for applying the basic philosophy of quality assurance, a clear set of guidelines for quality systems and processes, a means of satisfying contractual obligations, and readily available guidance and direction. SQ is measured by attributes such as ease of use, functionality, reliability, data quality, flexibility, and integration (DeLone et al., 2003:11). A comprehensive instrument for system quality was developed and validated by Sedera and Gable (2004:449), which resulted in nine attributes ease of use, ease of learning, user requirements, system features, system accuracy, flexibility, sophistication, integration, integration, and customization.

From previous research, also cited by Gorla et al (2010:213), the features of system quality is group into two broad categories; system features from the system designer perspective ( also known as system flexibility) and system features from the end user perspective (also called system sophistication). The system flexibility dimension reflects the fact that the system is designed with useful or required attributes (and without unnecessary features) and the fact that software modifications can be performed by the system designer with ease (Wang \& Strong, 1996:6). The system sophistication dimension denotes a user-friendly system (Miller \& Doyle, 1987:107) that is easy-to-use, user friendly, well documented, has a quick turnaround time (Bailey \& Pearson, 1983:531), and uses modern technology enabling user-friendliness of systems. 


\subsection{Service Quality In Higher Institution}

Service quality is crucial to every organisation. Baron, Harris, K., and Hilton (2009) claim that service quality is a highly abstract construct in contrast to goods quality, where technical aspects of quality are evident. According to O'Neill and Palmer (2004:42) service quality in higher education as the difference between what a student expects to receive and his/her perceptions of actual delivery. Clewes (2003:71) is of the opinions that one unresolved issue in the service quality field includes finding an appropriate definition for service quality and a suitable model for measuring service quality. Nevertheless, Lewis and Booms (1983:100) were one of the first to define quality in terms of services, and refer to service quality as a measure of how well the service level delivered matches customer's expectations.

A definition of quality revolves around the idea that quality has to be judged on the assessment of the user or employer of the service, and therefore, achieving quality has become an essential goal for most higher education institutions (Abdullah, 2006b:570). According to Jiang, Klein, Tesch and Chen (2003:27) service quality is the comparison between what the clients feel should be offered as their expectation and what is actually delivered according to their perceptions. It was revealed that many researchers are convinced that the service quality for the universities have positively impacted on the student at the higher institution (clients) satisfaction (e.g. Naik et. al., 2010; Spreng et. al, 1996:214; Sureshchandar, Rajendran \& Anantharaman 2002:365; Lewicka, 2011:5). It concluded that when the customers made a good perception about its service, the tendency to satisfy will higher. Furthermore, service quality will also impacted behavioural intention (Naik et.al., 2010). Guolla (1999:89) shows that students perceived service quality is an antecedent to student satisfaction.

\subsection{Student Self-Efficay In Higher Institution}

Self-efficacy refers to beliefs and confident in one's ability and capabilities to organize and accomplish the courses of action required producing given attainments (Bandura, 1997: 3). Self-efficacy, as a key element of social cognitive theory, appears to be a significant variable in student learning, because it affects students' motivation and learning (Pajares, 2006; Schunk, 2003:158). According to social cognitive theory, outcomes in one's life are result of human agency, or international actions that one takes which produces a result (Bandura, 2006:30). Self-efficacy assist students to decide how much effort they will spend on a task, how long they will persist when experiencing difficulties or challenges, and how resilient they will appear in detrimental situations.

Furthermore, the previous studies show that there are direct and indirect effects of students' self-efficacy on their achievements, relating to several grades and ability levels. (Carmichael \& Taylor, 2005:715; Lane, Lane, \& Kyprianou, 2004:250). Higher educational institutions put effort into helping students develop the required knowledge, skills and competencies. Although competent behaviour largely depends on acquiring knowledge and skills, this considerable amount of research findings points out that students' self-efficacy plays a predicting and mediating role in relation to students' achievements, motivation and learning. Therefore it appears crucial that higher education institutions pay attention to students' developing self-efficacy. Considering the factors that affect the development of students' selfefficacy can help higher educational institutions in developing and planning educational programmes that enhance students' self-efficacy. Pajares (2006:360) proposes that lecturers, as well as parents, therefore need to cultivate healthy academic self-efficacy in their students.

\section{Conceptual Model and Hypothesis Development}

Based on the literature reviewed the following conceptual model has been developed. Hypothesized relationships between research variables were developed thereafter. In the conceptualized model system quality, information quality, Service quality are the predictor variable, and while student self-efficacy is the outcome variable. 


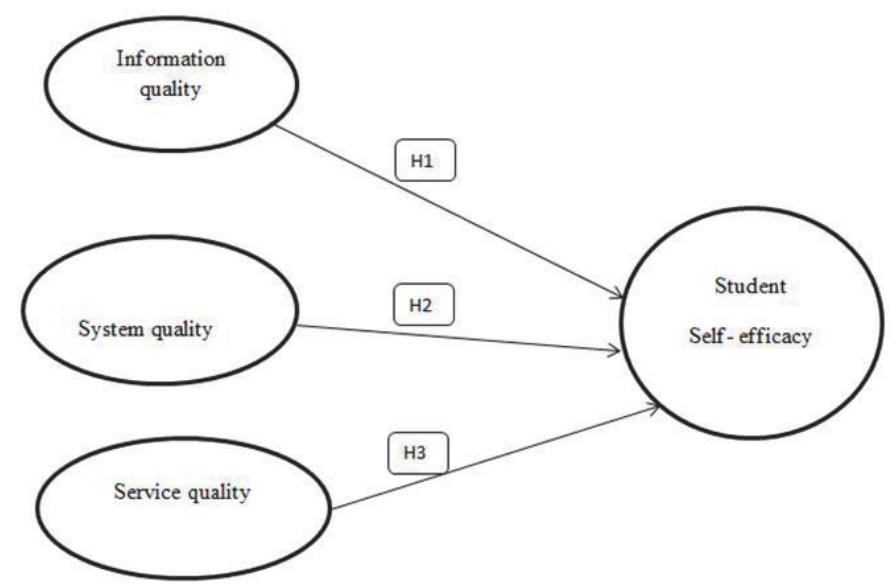

Figure 1: Conceptual Model

\subsection{Information quality and student self-efficacy}

Higher institutions around the globe have had many information system developed and implemented for the use of students and lecturers/academic personnel (Hall 2006:42). Kroeker (2000) is of the opinions that the prevalence of information quality system generated an expectation that all education institutions will have a virtual as well as a physical location, and that students can have access to the necessary information they need via a web browser for their efficiency. The capacity of information quality is to modify traditional understanding of the location of education, suggests the need for a completely different set of social and institutional infrastructures with which learning can be facilitated and to have a good outcome or result (Shields 2000).

According to social cognitive theory, there are four main sources of information that create students' self-efficacy: enactive mastery experiences, vicarious (observational) experiences, social persuasions and physiological and psychological states. Bandura, 1997 \& Palmer, 2006:337, espoused that students interpret the results of their activities and use these interpretations to develop beliefs about their capability to perform in subsequent tasks or activities. These deduced results of one's own performances create a sense of self-efficacy and Students also obtain information about their own capabilities by observing others. The basis for the information quality interpretations is constituted by the information students select and the rules they employ for weighting and combining them, the interpretations student make as a result of their activities and performances provide information on which self-efficacy is based (Pajares, 1997:5). Based on the above mentioned literature, this study posits that:

\section{H1: There is a positive relationship between information quality and student self-efficacy.}

\subsection{System quality and student self-efficacy}

A classy, well established, and implemented system quality is a necessary prerequisite to deriving an institution benefits and this will leads to student efficiency. Educational institutions that govern the outcome-based education have put a lot of effort into supporting their students' procurement of the required knowledge, skills, attitudes and competencies. Though competent behaviour is largely understood in terms of developing relevant knowledge, skills and attitudes, researchers in educational settings are increasingly drawing attention to the role students' thoughts and beliefs play in the learning process (Pajares, 2006:340; Schunk, 2003:160).

In Rai, Acton, Golden, \& Conboy, (2009) study indicates that a significant path has been found in system quality towards user satisfaction which can also leads to student self-efficacy. For quality of a system, it involves system's reliability, usability, user's adaptability towards the system (Seddon, \& Kiew, 1996:90), therefore, to satisfy students' selfefficacy at institutions of higher learning in South Africa, a good system quality is a necessity. Based on the above mentioned literature, this study posits that:

H2: There is a positive relationship between system quality and student self-efficacy. 


\subsection{Service quality and student self-efficacy}

DeShields, Kara, \& Kaynak, (2005:130) argue that the higher education sector needs to continue to deliver a high quality service and satisfy students in order to succeed in a competitive service environment and also endeavour to deliver a high quality of service and satisfy its students, who some may term 'participating customers or clients', to achieve sustainability in a competitive service environment. Nadiri, Kandampully, \& Hussain. (2009:525) emphasis that it is crucial for higher education providers to understand students' expectations and perceptions of what constitutes a quality service in order to fascinate students and assist with their desires in other to make them effective and efficient.

According to Lovelock \& Wirtz 2011, the level of service quality at higher institution or organisation can be measured by how much the service provided to consumers exceeds their expectations. It is expatiate that the ability of students to be efficiency and to attain their personal aims and standards depend to a certain degree on the qualities and behaviours of lecturers during the personal interaction in class. However, in the study of Kamal and Ramzi (2002:159), look upon the administrative side of higher institution, which attempt to measure student perception of registration and academic advising across different faculties and other administrative services to assure positive quality service that compliments the academic success. Based on the above mentioned literature, this study posits that:

H3: There is a positive relationship between service quality and student self-efficacy.

\section{Research Design and Methodology}

\subsection{Sample and data collection}

The target population for the study was South African university students in the Gauteng province. The sampling unit was the individual students who are university card holders. The survey method has the advantage of speed, is less costly and the researcher has control over respondent type. Students from the Vaal University of Technology were recruited as research assistants to distribute and collect the questionnaires. Out of 300 questionnaires distributed, 271 usable questionnaires were retrieved for the final data analysis, representing a response rate of 90 per cent. To eliminate differences in response patterns due to different reference points, all respondents were prompted to answer the questionnaires with reference to universities they are enrolled for.

\subsection{Measurement instrument}

A questionnaire containing 26 measurement items was designed based on previous work for the current study. Adjustments were made in order to fit the purpose of the reflective scales used in the current research context. A sevenitem scale used to measure information quality, was adapted from the previous studies by Lee, Strong, Kahn and Wang (2002), while a seven-item scale to measure system quality was adapted from Gorla, Somers and Wong (2010). Service quality used a seven-item scale measure adopted from Beaumont (2012), while a five-item scale on student self-efficacy was adapted from Siyez and Savi (2010) was used to measure student's self-efficacy. All the measurement items were measured on a 5 -point Likert-type scales that was anchored by $1=$ strongly disagree to $5=$ strongly agree to express the degree of agreement.

\subsection{Data analyses and results}

The research sample is described below. Then, the two-step procedure suggested by Anderson and Gerbing (1988) was applied to analyze the research data. That is, the accuracy of multi-item construct measures was assessed, followed by a test of the research model and hypotheses. In both data analysis stages, the current study mainly used StructuralEquation-Modeling (SEM) technique. The computation SEM software was AMOS 5.

\subsection{Sample description}

Descriptive statistics in Table 1 show the gender, age, nationality, home language and the academic qualifications of employees in the company. The profile indicates that there more female university students participated in the study compared to males. $58 \%$ were females and $42 \%$ were males. The age which is the mode is $21-25$ which constitutes $49 \%$ of the 5 different age groups. The study showed that there few students who are 31-35 years and 36 and above. South African students constituted the majority since the study was done in South African context. South African constitute 86\% 
and others constitute 14\%. In terms of language the majority speak Sotho language (99), followed by Zulu (73), English (57), Venda (31) and the least Africans (11) in numbers. Highest qualification, most of the students were matriculation holders (65\%), followed by those with diplomas (12\%), certificates holder (8\%), degree (7\%), postgraduate holders (7\%) again and other qualifications holders (1\%).

Table 7. 1: Sample demographic characteristics

\begin{tabular}{|c|c|c|}
\hline Gender & Frequency & Percentage \\
\hline Male & 131 & $48 \%$ \\
\hline Female & 140 & $52 \%$ \\
\hline Total & 271 & $100 \%$ \\
\hline Age & Frequency & Percentage \\
\hline $17-20$ & 98 & $37 \%$ \\
\hline $21-25$ & 134 & $49 \%$ \\
\hline $26-30$ & 17 & $6 \%$ \\
\hline $31-35$ & 11 & $4 \%$ \\
\hline 36 \& older & 11 & 4 \\
\hline Total & 271 & $100 \%$ \\
\hline Nationality & Frequency & Percentage \\
\hline South African & 232 & $86 \%$ \\
\hline Others & 39 & $14 \%$ \\
\hline Total & 271 & $100 \%$ \\
\hline Home Language & Frequency & Percentage \\
\hline English & 57 & $21 \%$ \\
\hline Afrikaans & 11 & $4 \%$ \\
\hline Zulu & 73 & $30 \%$ \\
\hline Sotho & 99 & $37 \%$ \\
\hline Venda & 31 & $11 \%$ \\
\hline Total & 271 & $100 \%$ \\
\hline Academic Qualifications & Frequency & Percentage \\
\hline Matriculation & 177 & $65 \%$ \\
\hline Certificate & 21 & $8 \%$ \\
\hline Diploma & 33 & $12 \%$ \\
\hline Degree & 18 & $7 \%$ \\
\hline Post Graduate Degree & 19 & $7 \%$ \\
\hline Others & 3 & $1 \%$ \\
\hline Total & 271 & $100 \%$ \\
\hline
\end{tabular}

\subsection{Measurement accuracy assessment}

Confirmatory factor analysis (CFA) was performed to examine the reliability, convergent and discriminant validity of the multi-item construct measures. BB3 had a factor loading less than 0.500 which is 0.320 and was deleted to improve the results. Initial specification search led to the deletion of some of the items in the constructs scale in order to provide acceptable fit. Overall acceptable CFA model fit indices used in this study included: the $X^{2} /$ (df) (Chi-Square/Degree of Freedom) value equal to or less than 3.00, the CFI (Comparative Fit Index) value equal to or higher than 0,90, Tucker and Lewis Index (TLI) value equal to or higher than 0,90, the Incremental Index of Fit (IFI) value equal to or higher than 0.90, and the Root Mean Square Error of Approximation (RMSEA) value equal to or less than 0.08. Recommended statistics for the final overall model assessment showed an acceptable fit of the measurement model to the data, that is: $X^{2} /(\mathrm{df})=1,982, \mathrm{CFI}=0,900, \mathrm{TLI}=0,902, \mathrm{IFI}=0,919$ and RMSEA $=0,059$. 
Table 7.2: Accuracy analysis statistics

\begin{tabular}{|c|c|c|c|c|c|c|}
\hline \multirow{2}{*}{ Research Construct } & \multicolumn{2}{|c|}{ Cronbach's Test } & \multirow{2}{*}{ C.R Value } & \multirow{2}{*}{ AVE Value } & Highest shared variance & Factor loading \\
\hline & Item-total & $\alpha$ value & & & & 0.500 \\
\hline BB1 & 0.500 & & & & & 0.583 \\
\hline BB2 & 0.501 & & & & & 0.562 \\
\hline BB4 & 0.504 & 0.701 & 0.700 & 0.796 & & 0.422 \\
\hline BB5 & 0.500 & & & & & 0.592 \\
\hline BB6 & 0.500 & & & & & 0.500 \\
\hline BB7 & 0.502 & & & & & 0.594 \\
\hline CC1 & 0.525 & & & & & \\
\hline CC2 & 0.500 & & & & & 0.500 \\
\hline CC3 & 0.535 & & & & & 0.632 \\
\hline CC4 & 0.500 & 0.791 & 0.790 & 0.765 & & 0.509 \\
\hline CC5 & 0.579 & & & & & 0.657 \\
\hline CC6 & 0.538 & & & & & 0.621 \\
\hline CC7 & 0.564 & & & & & 0.662 \\
\hline DD1 & 0.584 & & & & & 0.692 \\
\hline DD2 & 0.602 & & & & & 0.677 \\
\hline DD3 & 0.581 & & & & & 0.681 \\
\hline DD4 & 0.556 & 0.834 & 0.831 & 0.821 & & 0.629 \\
\hline DD5 & 0.587 & & & & & 0.613 \\
\hline DD6 & 0.604 & & & & & 0.617 \\
\hline DD7 & 0.554 & & & & & 0.599 \\
\hline EE1 & 0.575 & & & & & 0.627 \\
\hline EE2 & 0.641 & & & & & 0.677 \\
\hline EE3 & 0.663 & 0.843 & 0.843 & 0.820 & & 0.749 \\
\hline EE4 & 0.705 & & & & & 0.740 \\
\hline EE5 & 0.652 & & & & & \\
\hline
\end{tabular}

Note: C.R.: Composite Reliability; AVE: Average Variance Extracted; S.V.: Shared Variance; * Scores: 1 - Strongly Disagree; 3 - Neutral; 5 - Strongly Agree Measurement CFA model fits: $X^{2} /(\mathrm{df})=1,937, \mathrm{CFI}=0,900, \mathrm{TLI}=0,902, \mathrm{IFI}=$ 0,919 and RMSEA $=0,059$

Loadings of individual items on their respective constructs are shown in Table 2. The lowest value for individual item loadings for the research constructs is 0,500 . Therefore, all the individual item loadings either at the cutoff point or exceeded the recommended value of 0, 5 (Anderson and Gerbing, 1988). This indicates that all the measurement instruments are acceptable and reliable since all the individual items converged well and with more than $50 \%$ of each item's variance shared with its respective construct.

As indicated from the results shown in Table 2, the lowest obtained composite reliability (CR) value of 0,700 is well above the recommended 0.6 (Hulland, 1999), while the lowest obtained average variance (AVE) value is also above the recommended 0.5 (Fraering and Minor, 2006). This indicates that convergent validity was achieved and also this further confirms and excellent internal consistency and reliability of the measurement instruments used. Table 3 shows the discriminant validity was established by ensuring that average variance extracted (AVE) for each multi-item construct was greater than the shared variance between constructs (Nunnally \& Bernstein, 1994).

Table 7.3: Correlations between Constructs

\begin{tabular}{|l|c|c|c|c|c|}
\hline \hline \multirow{2}{*}{ Research Construct } & \multicolumn{5}{|c|}{ Construct Correlation } \\
\cline { 2 - 6 } & CC & CC & DD & EE & \\
\hline Information Quality (BB) & 1.000 & & & & \\
\hline System Quality (CC) & 0.535 & 1.000 & & & \\
\hline Service Quality (DD) & 0.500 & 0.605 & 1.000 & & \\
\hline Student's Self-Efficacy (EE) & 0.450 & 0.431 & 0.658 & 1.000 & \\
\hline \hline
\end{tabular}

As such all pairs of constructs revealed an adequate level of discriminant validity (see Table 3) because of the correlations are less than 1. By and large these results provided evidence for acceptable levels of research scale reliability. 
Table 7. 4: Analysis results of the research structural model and related hypotheses

\begin{tabular}{|l|c|c|}
\hline Path Coefficients & Hypothesis & Factor Loading \\
\hline Information Quality $(\mathrm{BB}) \rightarrow$ Student Self-Efficacy $(\mathrm{EE})$ & $\mathrm{H} 1$ & $0,226^{* *}$ \\
\hline System Quality $(\mathrm{CC}) \rightarrow$ Student Self-Efficacy (EE) & $\mathrm{H} 2$ & $0,200^{*}$ \\
\hline Service Quality (DD) $\rightarrow$ Student Self-Efficacy $(\mathrm{EE})$ & $\mathrm{H} 3$ & $0,732^{* *}$ \\
\hline
\end{tabular}

Note: a significance level $<0,05^{* *}$; b significance level $<0,1^{*}$; significance level $<0,001^{* * *}$

Research structural model fits: $\mathrm{X}^{2} /(\mathrm{df})=2.837, \mathrm{CFI}=0,900, \mathrm{TLI}=0,902, \mathrm{IFI}=0,901$, and RMSEA $=0,080$.

The research model was estimated and the hypotheses testing done. All the research model fit statistics were within the acceptable ranges, i.e., $\mathrm{X}^{2} /(\mathrm{df})=2.837, \mathrm{CFI}=0,900, \mathrm{TLI}=0,902, \mathrm{IFI}=0,901$, and RMSEA $=0,080$. The individual hypothesis testing results are shown in Table 4. The path co-efficients for $\mathrm{H} 1, \mathrm{H} 2, \mathrm{H} 3$ are $0.226,0.200$ and 0.732 respectively. $\mathrm{H} 1$ is significant at a confidence level ( $p$-value) of $0.05, \mathrm{H} 2$ is significant at a confidence level ( $\mathrm{p}$-value) 0.1 and $\mathrm{H} 3$ is significant at a confidence level (p-value) of 0.001 . Therefore the results support for all the proposed three hypotheses.

\section{Discussion of Findings and Results}

The study postulated that there is a positive relationship between all the 3 hypotheses.

(H1) There is significant positive influence of information quality on student self-efficacy in the South African universities. From the result of the path there is a relatively strong relationship between these two constructs because the $\mathrm{p}$ - value is less than 0.05 .

$(\mathrm{H} 2)$ There is significant positive relationship between system quality and student self-efficacy in South African universities. From the path $p$-value in deed shows there is a significant relationship between these two factors. Also the pvalue is less than 0.1 which shows a relatively strong relationship.

(H3) There is a strong positive relationship between service quality and Student self-efficacy and the relationship is strong because of the $p$-value is less than 0.001 . Where service quality is high it means the students self-efficacy will also skyrocket. Some interesting findings from this study are that service quality influence more the student self-efficacy than information quality and system quality. All in all the results shows that all the 5 hypotheses are supported in the whole model as hypothesized.

\section{Implications}

This study has both academic and practical implications. On the academic front, it provides added literature to the context of universities in South African which seem to have been neglected by researchers in terms of how they can increase self-efficacy to students. Most of the researches have been done in developed countries and research on universities in Africa is still scant so this research aim to fill the void by expanding the already existing literature.

As a practical contribution the study has implications to the top management employees at Universities. They should aim to provide quality information to students, improve system quality and service quality such that there is high student self-efficacy in universities. Measure might include student support services like instituting a strict code of conduct in universities and ensure that the code is understood, observed and enforced for effective results. Managers are required to work hand in hand with students to promote cooperation and encourage team spirit at universities. Cooperation and teamwork tend to increase student self-efficacy at universities if done in the right way. Incremental and transformational change is required for positive results to be realized since in South African education there is still a lot to be looked at from changing from being an apartheid county to a democratic country. There is need to improve in information quality, service quality and system quality for student self-efficacy to be high.

\section{Limitations and Future Research}

Although this study makes significant contributions to both academia and practice and also that due care was taken to achieve rigor, there are some limitations which open up avenues for further research. Firstly data were gathered from students and not the support staff. The results would be more informative if lecturers were also involved to hear their reasons for them to have high self-efficacy which can impact on student performance. Lecturers also need high quality information, good system quality and high service quality to disseminate quality education to students such that they 
become self-efficacy reasons. Therefore subsequent studies might consider collecting information from these two sides for empirical investigation.

Secondly this study focused on South Africa, extending this study to other African countries is also another research direction that might enable comparison of results with the current research findings.

\section{References}

Abdullah, F. (2006b). The development of HEdPERF: a new measuring instrument of service quality for the higher education sector. International Journal of Consumer Studies, 30(6), 569-581.

Alisha. A. R \& Dolmaci.M. (2013). The interface between self-efficacy concerning the self-assessment on students studying English as a foreign language. Procedia-Social and Behavioural Sciences, 70,873-881

Anderson, J.C. \& Gerbing, D.W. (1988). 'Structural equation modelling in practice: A review and recommended two step approach', Psychological Bulletin, 103(3): 411-423.

Andreassen T. W, Lindestad B. (1998) Customer Loyalty and Complex Services: The Impact of Corporate Image on Quality, Customer Satisfaction and Loyalty for Customers with Varying Degrees of Service Expertise. Int. J. Serv. Ind. Manage, 9(1): 7-23.

Aydin S, \& Ozer, G (2005). The Analysis of Antecedents of Customer Loyalty in Turkish Mobile Telecommunication Market. Eur. J. Mark, 7/8: $910-925$

Bailey, J.E., \& Pearson, S.W., (1983). Development of a tool for measuring and analysing computer user satisfaction. Management Science 29, 530-545.

Bandura, A. (1997). Self-efficacy: The exercise of control. New York: W.H. Freeman and Company.

Bandura, A. (2006). Adolescent development from an agentic perspective. In F. Pajares, \& T. Urdan (Eds.), Self-efficacy beliefs of adolescents. Greenwich, CT: Information Age Publishing.1-43.

Baron, S., Harris, K., \& Hilton, T. (2009). Services marketing: text and cases. 3rd ed. Basingstoke: Palgrave Macmillan.

Beaumont, D.J. (2012) Service Quality in Higher Education. The students' view point. A dissertation submitted to the University of Manchester for the degree of Bachelor of Science in the Faculty of Humanities.

Brady, M. K \& Cronin (2001). Some new thoughts on conceptualizing perceived service quality: A hierarchical approach. Journal of Marketing. 63(3) 34-49

Brennan, J. \& Shah, T. (2000). Managing quality in higher education: An international perspective on institutional assessment and change. Buckingham, UK: OECD, SRHE \& Open University Press.

Carmichael, C., \& Taylor, J. A. (2005). Analysis of student beliefs in a tertiary preparatory mathematics course. International Journal of Mathematical Education in Science and Technology, 36(7), 713-719.

Clewes, D. (2003). A Student-centred Conceptual Model of Service Quality in Higher Education. Quality in Higher Education, 9(1), 69-85.

Delone, W.H. \& Mclean, E.R., (1992). Information systems success: the quest for the dependent variable. Information Systems Research, 60-95

Delone, W. H. \& Mclean, E. R. (2003)'The Delone and McLean model of information systems success: A ten-year update', Journal of Management Information Systems. 19, (4) 9-30

Deshields JR, O. W., Kara, A., \& Kaynak, E. (2005). Determinants of business student satisfaction and retention in higher education: applying Herzberg's two-factor theory. International Journal of Educational Management, 19(2), 128-139.

Detlor, B., Hupfer, M., \& Ruhi, U. (2010). Internal factors affecting the adoption and use of government web sites. Electronic Government: An International Journal, 7(2), 120-136.

Fraering, M. \& Minor, M.S. (2006). 'Sense of community: An exploratory study of US consumers of financial services', International Journal of Bank Marketing 24(5): 284-306.

Guolla M. (1999). Assessing the teaching quality to student satisfaction relationship: applied customer satisfaction research in the classroom. J Mark Theory Pract. 7(3):87-97

Gorla, N., Somers, T. M. \& Wong, B. (2010). Organizational impact of system quality, information quality, and service quality. Journal of Strategic Information Systems 19 : 207-228

Hall, G (2006). Teens and Technology. New Directions for Youth Development 111: 41-52.

Hulland, J. (1999). 'Use of Partial Least Squares (PLS) in strategic management research: A Review of four recent studies', Strategic Management Journal 20(2): 195-204.

Huh, Y.U., Keller, F.R., Redman, T.C., \& Watkins, A.R., (1990). Data quality. Information and Software Technology 32, 559-565

Jackson. R, Karp .J, Patrick E, \& Thrower, A. (2006). Social Constructivism Vignette

Jiang J.J, Klien, D., Tesch \& Chen, H.G. (2003). Closing the user and provided Service Quality Gap: Communication of the ACM. ACM, 46(2):72-76.

Kamal A, \& Ramzi N (2002). Assuring quality service in higher education: registration and advising attitudes in a private university in Lebanon. Quality Assurance in Education, 10(4), 198-206.

Kahn, B.K \& Wang, R.Y. (2002). AIMQ: a methodology of information quality assessment. Information and Management Journal, 40.133-146

Ko, Y. J \& Pastore, D. L. (2004). Current issues and conceptualizations of service quality in the recreation sports industry, sport marketing quarterly. 13(2): 158-166.

Kroeker, B (2000). Changing Roles in Information Dissemination and Education. Garson, GD. Social Dimensions of Information Technology: Issues for the New Millennium. Hershey, PA: IDEA Group. 
Lane, J., Lane, A., \& Kyprianou, A. (2004). Self-efficacy, self-esteem and their impact on academic performance. Social Behaviour and Personality, 32, 247-256.

Lewicka, D. (2011). Creating Innovative Attitudes in an Organisation - Comparative Analysis of Tools Applied in IBM Poland and ZPAS Group. 1(1):1-12

Lewis, R. C., \& Booms, B. H. (1983). The marketing aspects of service quality, in Berry L., Shostack G. \& Upah, G (Eds), Emerging Perspectives on Services Marketing, AMA, Chicago, IL, 99-107.

Lovelock, C. H., \& Wirtz, J. (2011). Services marketing: people, technology, strategy. 7th ed. London: Pearson.

Miller, J., \& Doyle, B. A. (1987). Measuring the effectiveness of computer-based information systems in the financial services sector. MIS Quarterly 11, 107-124

Nadiri, H., Kandampully, J., \& Hussain, K. (2009). Students' perceptions of service quality in higher education. Total Quality Management \& Business Excellence, 20(5), 523-535.

Naik C. N. K, Gantasala S. B, \& Prabhakar G. V (2010) Service quality, Customer Satisfaction and Behavioural Intentions in Retailing European Journal of Social Sciences 17: 2.

Nelson, R.R., Todd, P.A., \& Wixom, B.H., (2005). Antecedents of information and system quality: an empirical examination within the context of data warehousing. Journal of Management Information Systems 21, 199-235.

Nunnally, J. \& Bernstein, I. (1994). Psychometric theory. $3^{\text {rd }}$ Edition. New York: McGraw-Hill.

O'Neill, M .A, \& Palmer, A. (2004). Importance-performance analysis: a useful tool for directing continuous quality improvement in higher education. Quality Assurance Education 12(1):39-52.

Palmer, D. H. (2006). Sources of self-efficacy in a science methods course for primary teacher education students. Research in Science Education, 36, 337-353

Pajares, F. (1997). Current directions in self-efficacy research. In M. Maehr, \& P. R. Pintrich (Eds.), Advances in motivation and achievement, Greenwich, CT: JAI Press.1-49

Pajares, F. (2006). Self-efficacy during childhood and adolescence: Implications for teachers and parents. In F. Pajares, \& T. Urdan (Eds.), Self-efficacy beliefs of adolescents. Greenwich, CT: Information Age Publishing: 339-367.

Parri, J. (2006), Quality in higher education, Vadyba/Management, 2 (11) 107-111.

Rai, H.,Acton, T., Golden, W., \& Conboy, K. (2009). Delone and Mc Lean success model as a descriptive tool in evaluating a virtual learning environment.

Redman, T.C., (1998). The impact of poor data quality on the typical enterprise. Communications of the ACM 41, 79-82

Schunk, D. H. (2003). Self-efficacy for reading and writing: Influence of modeling, goal setting and self-evaluation. Reading and Writing Quarterly: Overcoming Learning Difficulties, 19(2), 159-172.

Sedera, D., \& Gable, G., (2004). A factor and structural equation analysis of the enterprise systems success measurement model. In: Appelgate, L., Galliers, R., DeGross, J.I. (Eds.), Proceedings of the Twenty-Fifth International Conference on Information Systems. Association for Information Systems, Washington, DC, USA, : 449.

Seddon, P.B., (1997). A re-specification and extension of the Delone and McLean model of IS success. Information Systems Research 240, 240-253.

Seddon, P.B. \& Kiew, M.Y. (1996). A partial test and development of Delone and Mclean's model of IS success. Australia Journal of Information Systems, 4(1), 90-104.

Shields, M A. (2000). Technological Change, Virtual Learning, and Higher Education: Prospects, Problems, Potentials. Garson, GD. Social Dimensions of Information Technology: Issues for the New Millennium. Hershey, PA: Idea Group.

Siyez.D.M \& Savi. F. (2010). Empathy and self-efficacy and resiliency: an exploratory study of counselling students in Turkey. ProcediaSocial and Behavioural Sciences, 5, 459-463.

Spreng, R. A, \& Mackoy, R. D (1996). An Empirical Examination of a Model of Perceived Service Quality and Satisfaction. J Retailing, 72:201-214

Srikanthan, G., \& Dalrymple, J. (2003). Developing alternative perspective for quality in higher education. The International Journal of Educational Management, 17(3): 126-136.

Sureshchandar, G. S Rajendran, C \& Anantharaman, R.N. (2002). The Relationship Between Service Quality and Customer Satisfaction -a Factor Specific Approach. Journal of Service Marketing: 16 (4):363-379

Tang, S. F \& Hussin, S. (2011). Quality in Higher Education: A Variety of Stakeholder Perspectives. International Journal of Social Science and Humanity, 1( 2):126-131.

Van Dinther, M. Dochy, F \& Segers, M. (2011). Factors affecting students' self-efficacy in higher education. Educational research review, 6, 95-108.

Vroeijenstijn, A.I. (1995a) Improvement and accountability: navigating between Scylla and Charybdis, Higher Education Policy Series 30.

Wang, R.Y., \& Strong, D.M., (1996). Beyond accuracy: what data quality means to data consumers. Journal of Management Information Systems 12, 5-34

Zins, A. H. (2001) 'Relative attitudes and commitment in customer loyalty models'. International Journal of Service Industry Management: 12 (3): 269-294.

Zheng,Y. Zhao, K \& Stylianou, A. (2012). The impacts of information quality and systems quality on users' continuance intention in information exchange virtual communities: An empirical investigation. Decision Support Systems, 1-12. 